\title{
Towards Sustainable Corporate Governance and Organizational Growth of Quoted Health Care Companies in Nigeria
}

\author{
Johnson Ameh Obilikwu Dr Umar Abbas Ibrahim \\ Department of Business Administration, Nile University of Nigeria
}

\begin{abstract}
The purpose of this study is to examine the relationship between three sustainable corporate governance mechanisms (board independence, board size and gender diversity) and one organizational growth measures (return on asset-ROA) of quoted health care companies in Nigeria. Specifically, this study examines whether board independence, board size and gender diversity affects ROA of quoted health care companies in Nigeria. The population of the study was made up of ten health care companies listed in the Nigerian Stock Exchange (NSE). The study used secondary data for the years 2014-2018, with a sample size of eight listed health care companies based on firms with available data. The study employed multiple linear regression analysis at $90 \%$ confidence level due to the sample size of health care quoted companies with available data. The results showed that board independence is significantly related to ROA. However, from this result, board size and gender diversity are not significantly related to ROA. The study recommends that a high level of board independence with inclusion of reasonable number of non-executive directors in health care firms should be maintained to enhance financial growth. Based on the study result, it was recommended that rather than mere number, the caliber or qualities of people in the board should be considered for right decision-making. Similarly, the study concluded that gender has no significant impact on organizational growth. Areas for further research have also been recommended by this study.
\end{abstract}

Keywords: Corporate Governance, Board Independence, Board size, gender diversity, organizational growth.

DOI: $10.7176 / \mathrm{EJBM} / 12-14-08$

Publication date:May $31^{\text {st }} 2020$

\section{Introduction}

In recent times several calls were made by researchers, public, government, media for reform in corporate governance (Wang et al., 2019). Thus, corporate governance has become a hot buzzword in the global business world (Mukherjee and Sankar Sen, 2019). The call for reform was informed by collapses resulting from weak system of corporate governance especially in emerging markets (Arora and Sharma, 2016). The collapse in corporate governance structure and the grave consequences can be traced to the crises that resulted in the fall of Enron, WorldCom, Parmalat and other corporate bodies (Ibrahim and Zulkafli, 2016).

Corporate governance has been seen to be of great benefits to corporations. According to PWC (2015) the benefits of corporate governance in an organization include enhanced performance and decision-making, strategic/competitive advantage, all stakeholder confidence and trust, cost efficiency and improved ROI, market value and reputation, increased enterprise resilience and compliance/transparency. To achieve these benefits, corporations have devised some corporate governance mechanisms including board independence, board size and gender diversity. Similarly, Bhatt and Bhatt, (2017) opined that if implemented, corporate governance legislation and guidelines issued by government agencies and international bodies will assist firms and countries to attract foreign investments. Also, Good corporate governance helps to build an environment of trust, transparency and accountability necessary for fostering long-term investment, financial stability and business integrity, thereby supporting stronger growth and more inclusive societies (Oecd.org, 2019).

This study on governance is important to researchers as well as regulatory agencies. Firstly, it provides additional opinion on the impact of sustainable corporate governance on organizational growth. This is relevant because many studies have expressed conflicting opinions on the relationship between the two variables (Khurshed, I. and Shahid, J.K., 2016, Mohamad et al., 2020, Mohammed, 2020, Sarpong-Danquah et al., 2018). Secondly, many studies on corporate governance especially in emerging markets were focused on specific sectors like manufacturing firms, banks and agricultural companies (Mustapha et al., (2020), Roudaki, (2018), Ndemezo and Kayitana, (2018). Hence, this paper seeks to further research on corporate governance by conducting an empirical study to examine the relationship between sustainable corporate governance and organizational growth of health care companies in Nigeria. More so, insufficient studies have been conducted so far on sustainable growth in Nigerian business operations especially with regard to corporate governance; hence the study intends to contribute to the existing body of knowledge. This empirical study will utilize data from eight listed health care companies in Nigeria between 2014 and 2018. This represents 40 firm- year observations based on firms with available data. Therefore, this paper examined the relationship between three sustainable corporate governance mechanisms (board independence, board size and gender diversity) and organizational growth measures (return on asset-ROA) of quoted health care companies in Nigeria. The paper is subsequently organized as follows: Statement of problem 
followed by research objectives. The next section is the research questions. Statement of hypothesis is next followed by literature review. The remaining sections are materials/methodology, data analysis, discussion of findings, conclusion/recommendations, areas for further research and references.

\subsection{Statement of problem}

Many factors are responsible for the failure of businesses. Some are internal while others are external factors such as economy, politics, competitors and even customers. However, most companies fail due to internal crises relating to poor corporate governance. Corporate governance is now a global phenomenon and many businesses have established the link between sustainable corporate governance and organizational growth. The sudden collapse of big corporations like Enron and WorldCom give credence to the fact that any organization can fail due to corporate governance failure.

Many studies have examined the relationship between corporate governance and organizational performance in different business sectors across the globe. These include studies conducted by Ndemezo and Kayitana, (2018) on the effects of corporate governance on performance of Rwandese manufacturing firms, Mohamad et al., 2020 on the impact of governance on firm performance of listed Malaysian firms and Roudaki, J. (2018) on the effect of corporate governance structures on firm performance in large agricultural companies in New Zealand. Most of these studies were focused on business sectors such as manufacturing and agricultural firms. The focus of this study however, is on health care companies. Similarly, while researchers like Mbu-Ogar, Effiong and Abang (2017) investigated the impact of corporate governance on the performance of Nigerian manufacturing firms, the degree of the relationship between corporate governance mechanisms and organizational growth of health care companies in Nigeria has not been amply investigated. It is as against this background that this study seeks to investigate the link between corporate governance and the organizational growth of health care companies in Nigeria. The study will examine the impact of corporate governance mechanisms such as board independence, board size and gender diversity on the return on asset of health care companies in Nigeria.

\subsection{Research objectives}

The objectives of this study include the following:

i. To determine the relationship between board independence and return on asset (ROA) of health care companies in Nigeria.

ii. To examine the relationship between board size and return on asset (ROA) of health care companies in Nigeria.

iii. To evaluate the relationship between gender diversity and return on asset (ROA) of health care companies in Nigeria.

\subsection{Research questions}

The following research questions are put forward.

a) Is there any significant relationship between board independence and return on asset (ROA) of health care companies in Nigeria?

b) To what extent does board size affect the return on asset (ROA) of health care companies in Nigeria?

c) How does gender diversity affect the return on asset (ROA) of health care companies in Nigeria?

\subsection{Research Hypotheses}

The hypotheses are stated in their null form.

H01: Board independence has no positive significant impact on return on asset (ROA) of health companies in Nigeria

H02: Board size has no significant relationship with return on asset (ROA) of health companies in Nigeria.

H03: Gender diversity has no significant relationship with return on asset (ROA) of health companies in Nigeria

\section{Literature review}

2.1 Conceptual framework

2.1.1 Corporate governance

There is no single definition of corporate governance rather it has been viewed in various ways.

OECD in 1999 defined corporate governance as "the system by which business corporations are directed and controlled". Corporate governance is also seen as a relationship among stakeholders that determine and control the strategic direction and performance of an organization (Chaudhary and Gakhar, 2018).

Various scholars have measured corporate governance using different proxies such as institutional ownership, managerial ownership, board size, audit committee size, director's remuneration, board meeting, board independence, ownership structure, as well as board gender diversity (Olaoye, Nwaobia and Olumuyiwa, 2016, Mukherjee and Sankar Sen, 2019, Kyaw, Olugbode and Petracci, 2017, Y1lmaz, 2018). 
Figure 1 below shows the corporate governance mechanism and the growth measures used in this study.

Corporate governance is the independent variable while the dependent variable is organizational growth. The corporate governance mechanisms applicable to this study are board independence, board size and gender diversity. Organizational growth on the other hand was measured by return on asset (ROA).

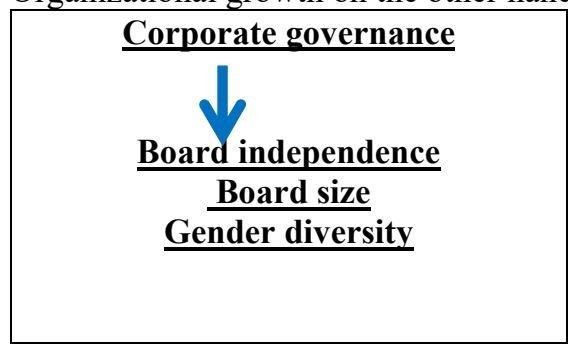

\subsubsection{Organizational Growth}

The words "organizational Growth" can be defined in various ways. It means different thing to different people. However, from a financial perspective, sustainable growth implies "an affordable growth that can be sustained profitably for future benefits (Mukherjee and Sankar Sen, 2019). There is also growth when an organization experiences an expansion in terms of size in the form of increased number of branches and employees which may eventually lead to an increase in revenue and profit (Olaoye, Nwaobia and Olumuyiwa, 2016).

There are several ratios to measure the company's financial performance and these ratios can be broadly classified into five categories such as liquidity ratio, profitability ratio, solvency ratio, efficiency ratio, and leverage ratio. Profitability ratios measure the performance of the company in terms of the profit generated over the period being considered (Mohammed, 2020). In this study, the measure of growth examined is return on asset. Return on asset indicates a firm's profitability relative to its asset. The higher the return on asset figure, the higher earning the firm is generating from its investments, Return on asset is a profitability ratio used to assess the firm's ability to convert its assets to generate profit and value to owners of the business. Return on asset is a popular and reliable metric used to assess management efficiency in utilizing economic resources.

2.1.3 Board Size and Corporate Sustainable Growth

Board size reflects the number of directors on the board of a corporate organization (Mbu-Ogar, Effiong and Abang, 2017). Corporate sustainable growth depends on a combination of factors including the number of directors on the board and the quality of the members on the board. However, while some researchers are of the opinion that a large board size provides the expertise and skills to improve firm performance, others suggest that with large board size the external directors become easily manipulated by the CEO. Organizational performance can also decline due to large board size as it becomes difficult to organize activities of large number of board members.

There are, however, contradicting papers on the relationship between board size and firm performance. While Mohammed, (2020) found a statistically significant relationship between board size and firm performance, Sarpong-Danquah et al., (2018) indicated in their paper that board size does not have any significant statistical relationship with firm performance. Mukherjee and Sankar Sen, (2019) in their paper established that board Size exercise a profound influence in explaining the Corporate Sustainable Growth (CSG).

2.1.4 Board gender diversity and Corporate Sustainable Growth

Prior research paper established that the proportion of women director on the corporate boards has significant impact on organizational performance. Kyaw, Olugbode and Petracci, (2017) posit that board gender diversity does not only enrich the board but it also broadens boardroom discussions and perspectives including the ultimate increase in corporate social performance. This transforms to firm environmental, social and overall performances.

It was emphasized that Female directors on boards can potentially increase firm performance by suggesting different approaches and views to board discussions, sending positive signals to the stakeholders of the company, building a positive firm image and maintaining a competitive advantage (Kılıç and Kuzey, 2016). In addition, low gender diversity could deprive boards of the skills and resources held by female directors, potentially leading to sub optimal decisions and economic under performance (Sabatier, 2015).

\subsubsection{Board Independence and Corporate Sustainable Growth}

The composition of the board of directors is a vital aspect of board characteristics, and pertains to the number of outside directors on the board (Alhumoudi, 2016). Many studies opined that a high proportion of none executive directors (NED) sitting on the board will protect the interest of shareholders. Based on the expertise and relevant experience of external directors, the interest of shareholders is considered in firm governance. Khurshed, I., and Shahid, J.K., (2016) concluded that that board independence is positively associated with corporate performance. On the contrary, Mohamad et al., (2020) concluded that non-executive directors does not affect positively on the performance of the firms, recommending that every board should include one third of non-executive directors. 


\subsection{Theoretical framework}

According to Mukherjee and Sankar Sen, (2019), several theories have been used overtime to examine the relationship between corporate governance practices and firms performance. These include Agency theory, Stewardship theory, Stakeholders theory, and Resource Dependence theory. These theories are discussed in this section. This study is supported by the Agency theory.

One of the reasons for the wide use of agency theory based approaches in the theoretical frameworks is that it allows the study of the consequences of the separation between ownership and control in public companies (Kumar and Zattoni, 2017). Jensen and Meckling, (1976) characterized the agency conflict between the ownermanager and outside shareholders as deriving from the manager's tendency to appropriate perquisites out of the firm's resources for his own consumption. Thus, Principal-agent problem arises when the self-interest of the agent conflicts with the interest of the principal. Corporate governance can be used to address this problem by ensuring that the agents appointed by the principal act in the best interest of the owners. In emerging market like Nigeria, this principal-agent problem is apparent given the lack of transparency in governance as revealed in some businesses and this is also applicable to Nigerian health care companies. The ability to maintain high profitability of a firm depends on the robustness of corporate governance in making healthy strategic decision (Nwonyuku, 2016).

\subsection{Empirical review}

Several research papers examined the relationship between corporate governance and organizational performance with mixed results. Some of these results are presented below.

\subsubsection{Board independence and Firm Performance}

Yllmaz, (2018) concluded that there is a negative but significant relationship between board independence and firm performance proxied by net profit margin in a study conducted to examine the relationship between corporate governance and financial performance of Oman companies at Muscat Securities Market. However, Mohamad et al., (2020) in a study of the relationship between corporate governance and firm performance with the sample data of 180 listed companies of Malaysia during the period 2013-2017 concluded that non-executive directors does not affect positively on the performance of the firms.

\subsubsection{Board size and Firm Performance}

Worasatepongsa, (2017) in examining the influence of Good Corporate Governance (GCG) on financial performance of the Stock Exchange of Thailand (SET) found that number of board directors is one of the factors of Good Corporate Governance (GCG) which had significant influence on the financial performance. Nonetheless, Dzingai and Fakoya, 2017 examined the effect of Corporate Governance Structure on the Financial Performance of Johannesburg Stock Exchange (JSE)-Listed Mining Firms and reported a weak negative correlation between firm's performance and board size.

2.3.3 Gender Diversity and Firm Performance

FATIMA YAWO, (2018) evaluated the relationship between board gender diversity and Firm Performance in Nigerian Banking Industry and concluded that firm performance of the banks in Nigeria are not affected by the number of female Board Members. Similarly, Isah and Iliya, (2018) in their study argued that board diversity is not much related with the firm financial performance instead their experiences and ability to control and direct are the qualities that really matter.

\section{Methodology}

A sample of eight health care firms listed on Nigeria Stock Exchange (NSE) was obtained from a population of the ten listed firms over a period of five (5) years yielding 40 firm year observations. The eight health care firms were conveniently chosen on accessibility and availability of their annual financial reports within the period understudy (2014-2018). The study examined the degree of casual relationship between three sustainable corporate governance mechanisms (board independence, board size and gender diversity) and one organizational growth measures (return on asset-ROA) of quoted health care companies in Nigeria.

The study utilized multiple regression analysis since it can predict the value of a variable based on the value of two or more other variables. This regression model was used to analyze the relationship between the corporate governance variables and firm performance measures at $90 \%$ confidence level based on the sample size of health care quoted companies with available data. 
Variable Description

Table 1. Measurement of variables used in the study

\begin{tabular}{|c|c|c|}
\hline Variables & Meaning & Measurement \\
\hline \multicolumn{3}{|c|}{$\begin{array}{l}\text { Variables relating to corporate } \\
\text { governance. }\end{array}$} \\
\hline $\mathrm{BI}$ & $\begin{array}{l}\text { Board } \\
\text { Independence }\end{array}$ & $\begin{array}{l}\text { Proportion of outside directors or none executive } \\
\text { directors (NED) sitting on the board. }\end{array}$ \\
\hline $\mathrm{BS}$ & Board Size & Number of directors on the board \\
\hline $\mathrm{G}$ & Gender diversity & Proportion of female directors on the board \\
\hline \multicolumn{3}{|c|}{ Variables relating to growth } \\
\hline ROA & Return on Assets & $\frac{\text { Profit after tax }}{\text { Total assets }}$ \\
\hline
\end{tabular}

\subsection{Data Analysis}

Descriptive Statistics

Table 2 below shows the descriptive statistics of the dependent and explanatory variables for the study. The result shows that in Nigeria, based on the mean value, majority of directors ( 74 percent) on boards of health care firms are independent. The result also indicated that board size have little in common with a minimum of five (5) and a maximum of twelve (12) board members. The average board size of health care firms in Nigeria is approximately eight (8) indicating the significance such firms place on corporate governance.

Regarding board gender diversity, an average of 10.3 percent females are present on boards of health care firms in Nigeria. Our results reveal that the maximum representation of females on health care firms' board is three (3) while some firms do not have a single female on their boards. In terms of ROA, the results show that there is a huge gap in terms of profitability among the health care listed firms during the years under review. While some made profits, others made losses during the years.

Table 2. Descriptive Statistics

\begin{tabular}{|l|l|l|l|l|l|}
\hline \multicolumn{7}{|l|}{} \\
\hline Variables & Observation & Minimum & Maximum & Mean & Standard dev \\
\hline BI & 40 & 0.44 & 0.89 & 0.736 & 0.144 \\
\hline BS & 40 & 5 & 12 & 8.3 & 1.800 \\
\hline G & 40 & 0 & .38 & 0.103 & 0.120 \\
\hline ROA & 40 & -.35 & .26 & -.023 & .123 \\
\hline So
\end{tabular}

Source: Computation From STATA software

Table 3 below shows the result of the pairwise correlational matrix. This shows the relationship between the variables of the study. The result shows a weak negative relationship between ROA and board independence (BI) given that $r=-0.3292$ and since the $p$-value of 0.03806 is lower than 0.1 the relationship between $\mathrm{BI}$ and ROA is said to be statistically significant at $90 \%$ confidence level. This means that the board independence was inversely proportional to firms' ROA. The higher proportion of board independence will cause lower firms' ROA. The result also shows a positive but insignificant relationship between board size (BS) and ROA given that $\mathrm{r}=+0.069457$ and $\mathrm{P}$-value of 0.670201 is greater than 0.1 at $90 \%$ confidence level. The relationship is weak since $\mathrm{r}=0.069457$. This means that board size was proportional to firms' ROA. A large size of board will increase firms' ROA. The relationship between gender diversity (GEN) and ROA is positive and weak, given that $\mathrm{r}=+0.088846$. However, since the p-value of 0.585633 is greater than 0.1 at $90 \%$ confidence level, the relationship between GEN and ROA is insignificant.

Table 3. Correlation Matrix

\begin{tabular}{|l|l|l|l|l|}
\hline & $B I$ & $B S$ & GEN & ROA \\
\hline BI & 1 & & & \\
\hline BS & 0.112547 & 1 & & \\
\hline GEN & -0.60067 & 0.107718 & 1 & \\
\hline ROA & -0.3292 & 0.069457 & 0.088846 & 1 \\
& 0.03806 & 0.670201 & 0.585633 & \\
\hline
\end{tabular}

Source: Author's computation

Table 4 below shows the result of multicollinearity test conducted to determine if there is an intercorrelation or inter -association amongst independent/explanatory variables in a multiple regression model. The table shows that all the independent variables have a tolerance value greater than 0.10 and the Variant Inflation Factor (VIF) 
is less than 10. Therefore, the regression result has no multicollinearity problem.

Table 4. Multicollinearity test

\begin{tabular}{rrr} 
Variable & VIF & 1/VIF (Tolerance) \\
\hline BI & 1.65 & 0.607 \\
BS & 1.06 & 0.939 \\
GEN & 1.64 & 0.608 \\
\hline Mean VIF & 1.45
\end{tabular}

From Table 5 below, contrary to expectation, the regression result shows that board independence and return on asset (ROA) have significant negative relationship at 10 percent significance level since the P-value $(0.024)$ is lower than 0.1 and the value of $\beta$ is negative. Therefore, the null hypothesis is accepted. Therefore, it can be concluded that Board independence has no positive impact on return on asset (ROA) of health care companies in Nigeria.

The result also shows that there is no significant relationship between board size and ROA since the P-value of 0.375 is greater than 0.1 at 10 percent significance level. Therefore, the null hypothesis is accepted. The value of $\beta$ is positive which implies that board size shows an insignificant positive association with firm growth.

The regression result shows that there is a negative insignificant relationship between gender diversity and ROA since the P-value of 0.288 is greater than 0.1 at 10 percent significance level and the value of $\beta$ is negative. Therefore, the null hypothesis is accepted.

The adjusted R-squared value of 0.07 in the result shows the proportion of variance in organizational growth that accounted for board independence, board size, and gender diversity, whereas the R-squared value of 0.14 indicates the proportion of variance in organizational growth due to the interactions of the independent variable, considering the degree of freedom.

Table 5. Results of multiple linear regression analysis that examined the association between corporate governance and ROA

\begin{tabular}{|l|l|l|l|l|}
\hline Variables & Beta Coef & Standard Error & t-Statistic & P-value \\
\hline $\mathrm{BI}$ & -.3994819 & .1691002 & -2.36 & 0.024 \\
\hline $\mathrm{BS}$ & .0097482 & .0108511 & 0.90 & 0.375 \\
\hline $\mathrm{G}$ & -.2176837 & .2020052 & -1.08 & 0.288 \\
\hline cons & .2125023 & .1484613 & 1.43 & 0.161 \\
\hline Number of obs $=40$ & & \\
$\mathrm{~F}(3, \quad 36)=2.01$ & & \\
Prob $>\mathrm{F}=0.1298$ & & \\
R-squared $=0.1435$ & & \\
Adj R-squared $=0.0722$ & & \\
Source: Author's Computation From STATA software & & \\
\hline
\end{tabular}

\section{Discussion of findings}

From the regression result, the first null hypothesis was accepted. The result shows that board independence and return on asset (ROA) have significant negative relationship at 10 percent significance level. Thus, higher number of non-executive directors will adversely impact on the financial growth of health care listed firms in Nigeria. This implies that the non-executive directors have been influenced by management of Nigerian health care firms. This result was also supported by the research conducted by Palaniappan, (2017).

The second hypothesis was also accepted. The result shows an insignificant positive association between board size and firm growth indicating that the number of the directors on the board is not important; rather what really matter is their skill and experience. This result contradicted the research conducted by Arora and Sharma, (2016) which concluded that board size is negatively related to ROA.

The third hypothesis was accepted. The result shows that there is a negative insignificant relationship between gender diversity and ROA. This implies that an increase in women representation in the board of directors of listed health care companies in Nigeria could have little impact on financial performance of these companies. Therefore, female representation on the board should be based on the skills and qualities that women bring to the table. This result contradicted the research conducted by Adesanmi et al., (2019) that observed a significant positive relationship between gender diversity and firm's financial performance.

\section{Conclusion/recommendations}

This paper has examined the relationship between organizational growth measures and corporate governance mechanisms of listed health care companies in Nigeria. . This study revealed that there is a significant negative relationship between board independence and return on asset (ROA) of health care listed firms in Nigeria. The findings of current study mirrored the agency theory. By this theory, principal-agent problem is addressed by corporate governance measures such as board independence. Therefore, it is recommended that a high level of 
board independence with inclusion of reasonable number of non-executive directors in health care firms should be maintained to enhance financial growth. The study also revealed that there is no significant relationship between board size and ROA. The study recommends that health care companies should consider the caliber or qualities of people in the board rather than mere number for right decision-making. Similarly, based on the result which shows a negative insignificant relationship between gender diversity and ROA, gender should not be considered an important factor in the selection of board members.

\section{Areas for further research}

It is recommended that future researchers should examine other variables not considered in this study. Based on available data further research should consider independent variables such as women's education background or years of tenure. Similarly, further research should examine dependent variables like Return on Sales (ROS) and Net Profit Margin (NPM) as proxies for firm's financial growth. In addition, further studies on corporate governance in emerging market should focus on listed firms in other sectors such as consumer goods, construction/real estate and ICT. The use of alternative methodological approach should also be considered for further research.

\section{References}

Adesanmi, A.D., Sanyaolu, O.A., Isiaka, M.A. and Fadipe, O.A. (2019). Empirical analysis of board diversity and the financial performance deposit money banks in Nigeria. Accounting, pp.127-134

Alhumoudi, H.Y. (2016). Corporate Governance Mechanisms and Firms' Performance: An Empirical Analysis of Firms Listed on the Saudi Stock Exchange. International Journal of Accounting and Financial Reporting, $6(2)$, p. 101

Arora, A. and Sharma, C. (2016). Corporate governance and firm performance in developing countries: evidence from India. Corporate Governance: The international journal of business in society, 16(2), pp.420-436.

Bhatt, P.R. and Bhatt, R.R. (2017). Corporate governance and firm performance in Malaysia. Corporate Governance: The international journal of business in society, 17(5), pp.896-912.

Chaudhary, N. and Gakhar, K. (2018). Corporate governance and financial performance with a perspective on board size and frequency of board meetings: Empirical evidence from India. Drishtikon: A Management Journal, 9(1), pp.37.

Oecd.org. (2019). Corporate governance - OECD. [online] Available at: http://www.oecd.org/corporate/.

Dzingai, I. and Fakoya, M. (2017). Effect of Corporate Governance Structure on the Financial Performance of Johannesburg Stock Exchange (JSE)-Listed Mining Firms. (2017). Sustainability, 9(6), p.867.

FATIMA YAWO, A. (2018). A Board Gender Diversity and Firm Performance: An Evaluation of the Nigerian Banking Industry. RA Journal Of Applied Research, 04(06).

Ibrahim, H.I. and Zulkafli, A.H. (2016). Corporate governance, HRM practices and organizational performance. Socio-Economic Problems and the State, 14(1), pp.30-40.

Isah, N. and Iliya, R. (2018). The Effect of Corporate Gender Diversity on Board and Firm Performance. SSRN Electronic Journal.

Jensen, M.C. and Meckling, W.H. (1976). Theory of the firm: Managerial behavior, agency costs and ownership structure. Journal of Financial Economics, 3(4), pp.305-360.

Khurshed, I. and Shahid, J.K. (2016). Corporate Governance and its Impact on Profitability of the Pharmaceutical Industry in Pakistan. Journal of Managerial Sciences, 10(1), pp.73-82.

Kiliç, M. and Kuzey, C. (2016). The effect of board gender diversity on firm performance: evidence from Turkey. Gender in Management: An International Journal, 31(7), pp.434-455.

Kumar, P. and Zattoni, A. (2017). Agency Conflicts and Corporate Governance. Corporate Governance: An International Review, 25(4), pp.220-221.

Kyaw, K., Olugbode, M. and Petracci, B. (2017). Can board gender diversity promote corporate social performance? Corporate Governance: The international journal of business in society, 17(5), pp.789-802.

Mbu-Ogar, B.G.., Effiong A.S. and Abang O.J. (2017). Corporate Governance and Organizational Performance: Evidence from the Nigerian Manufacturing Industry. Journal of Business and Management, 19(8), pp. 46-51.

Mohamad, S., Pantamee, A.A., Keong, O.C. and Garrett, K.W.C. (2020). Corporate Governance and Firm Performance: Evidence from Listed Malaysian Firms. International Journal of Psychosocial Rehabilitation, 24(02), pp.3668-3678.

Mohammed, H.D. (2020). Corporate Governance and Financial Performance of Quoted Companies in Nigeria. European Journal of Business and Management, 12(6).

Mukherjee, T. and Sankar Sen, S. (2019). Impact of Corporate Governance on Corporate Sustainable Growth. International Research Journal of Business Studies, 12(2), pp.167-184.

Mustapha, U.A., Rashid, N., Bala, H. and Musa, H. (2020). Corporate Governance and Financial Performance of Nigeria Listed Banks. Journal of Advanced Research in Dynamical and Control Systems, 12(1), pp.5-10. 
Ndemezo, E. and Kayitana, C. (2018). Corporate Governance, Corporate Entrepreneurship and Firm Performance: Evidence from the Rwandese Manufacturing Industry. Indian Journal of Corporate Governance, p.097468621880671.

Nwonyuku, K.N. (2016). Evaluating the Influence of Corporate Governance on Firm Profitability: The Case of Quoted Food and Beverages Companies in Nigeria. SSRN Electronic Journal.

Olaoye, S., Nwaobia, A. and Olumuyiwa, O. (2016). Corporate Governance and Organizational Growth: An Assessment of the Nigerian Manufacturing Industry. Journal of Accounting and Financial Management, 2. pp.10-23.

Palaniappan, G. (2017). Determinants of corporate financial performance relating to board characteristics of corporate governance in Indian manufacturing industry. European Journal of Management and Business Economics, 26(1), pp.67-85.

Corporate Governance in the Boardroom A practical perspective. (2015). [online] Available at: https://www.pwc.com/ee/et/publications/pub/corporate-governance-in-the-boardroom.pdf..

Roudaki, J. (2018). Corporate governance structures and firm performance in large agriculture companies in New Zealand. Corporate Governance: The international journal of business in society, 18(5), pp.987-1006.

Sabatier, M. (2015). A women's boom in the boardroom: effects on performance? Applied Economics, 47(26), pp.2717-2727.

Sarpong-Danquah, B., Gyimah, P., Afriyie, R.O. and Asiama, A. (2018). Corporate Governance and Firm Performance: An Empirical Analysis of Manufacturing Listed Firms in Ghana. Accounting and Finance Research, 7(3), p.111.

Wang, Y., Abbasi, K., Babajide, B. and Yekini, K.C. (2019). Corporate governance mechanisms and firm performance: evidence from the emerging market following the revised CG code. Corporate Governance: The International Journal of Business in Society, 20(1), pp.158-174.

Worasatepongsa, P. (2017). The Influence of Good Corporate Governance on the Financial Performance Case Study: Companies Listed on SET Year 2013-2015. The SIJ Transactions on Industrial, Financial \& Business Management, 05(05), pp.01-04.

Yilmaz, İ. (2018). Corporate Governance and Financial Performance Relationship: Case for Oman Companies. journal of accounting finance and auditing studies (JAFAS), 4(4), pp.84-106. 